\title{
Covariation between tree size and shade tolerance modulates mixed-forest productivity
}

\author{
Thomas Cordonnier $^{1}$ (D) $\cdot$ Thomas Bourdier $^{1} \cdot$ Georges Kunstler $^{1} \cdot$ Christian Piedallu $^{2} \cdot$ Benoît Courbaud $^{1}$
}

Received: 22 March 2018 / Accepted: 15 October 2018 / Published online: 22 November 2018

(C) INRA and Springer-Verlag France SAS, part of Springer Nature 2018

\begin{abstract}
- Key message In tree communities, tree size inequality reduces productivity and interacts with tree shade tolerance to modulate stand productivity, with a higher productivity in stands where shade-intolerant species dominate shade-tolerant species in size.

- Context Positive diversity-productivity relationships have been reported in different plant communities, including tree communities. These effects may be strongly related to both structural diversity and functional diversity, but also to their interactions if there is a non-random distribution of species functional characteristics among canopy layers.

- Aims We explore the relative effects on forest productivity of tree species diversity, tree size inequality, and species shade tolerance diversity, as well as the effect of the distribution of tree shade tolerance in the canopy.

- Methods We used 11,054 mixed-species forest plots from the French Forest Inventory (IGN) distributed throughout France (2006-2011). We analyzed the effects of species richness, shade tolerance diversity, and height inequality on forest plot productivity, represented by basal area annual increment over a period of 5 years, while controlling for first-order structure characteristics (basal area and quadratic mean diameter) and environmental factors (soil water budget and sum of growing degree days). Using the covariance between tree height and shade tolerance in mixed species canopies, we also explored the effect of the distribution of species' shade tolerance among canopy layers.

- Results The results showed a positive effect of species richness (effect size, 0.02) and a negative effect of height inequality $(-0.05)$ on mixed-forest productivity. We also showed that a negative covariance between shade tolerance and height (e.g., higher proportion of shade-tolerant species in lower height classes) increased productivity (0.01). Shade tolerance diversity did not affect productivity.
\end{abstract}

Handling Editor: Céline Meredieu and François de Coligny

\section{Contribution of the co-authors}

TC conceived the original idea; he took part in the design, the writing, and the analysis of the data. TB defined the design of the study, wrote the first draft, and performed first analyses. CP produced climate data and edited the paper. GK and BC contributed significantly to the design of the study and the writing of the paper.

This article is part of the topical collection on Mensuration and modelling for forestry in a changing environment

Thomas Cordonnier thomas.cordonnier@irstea.fr

Thomas Bourdier

thomas.bourdier@gmail.fr

Georges Kunstler

georges.kunstler@irstea.fr

Christian Piedallu

christian.piedallu@agroparistech.fr
Benoît Courbaud

benoit.courbaud@irstea.fr

1 Univ. Grenoble Alpes, Irstea, UR LESSEM, 2 rue de la Papeterie, BP76, 38402 Saint-Martin-d'Hères cedex, France

AgroParisTech, Inra, Silva, Université de Lorraine, 54000 Nancy, France 
- Conclusion In tree communities, as shown previously in monospecific forest stands, tree size inequality reduces productivity. This effect is modulated by the distribution of shade tolerance among canopy layers. Previous studies on species diversity effect have generally overlooked the importance of the size structure and the size hierarchy of functional characteristics. These effects are, however, crucial and deserve to be explored in greater detail.

Keywords Species richness $\cdot$ Size inequality $\cdot$ Stand productivity $\cdot$ Functional characteristics $\cdot$ Gini index

\section{Introduction}

In today's context of global biodiversity loss, many authors have studied the effect of species diversity on productivity, a key ecosystem function (Farnsworth et al. 2017). Although species diversity-productivity relationships have been shown to take various forms in empirical studies (Huston 2000; Forrester and Bauhus 2016; Díaz and Cabido 2001; Whittaker 2010), the dominant pattern seems to be a positive effect in all types of plant communities, from grasslands (Tilman et al. 2012; Cardinale et al. 2012; Grace et al. 2016) to forests (Vilà et al. 2007; Piotto 2008; Paquette and Messier 2011; Zhang et al. 2012; Gamfeldt et al. 2013; Liang et al. 2016; Duffy et al. 2017). However, several recent studies highlighted that using only species diversity (species richness or other indexes integrating species' relative abundance, e.g., the Shannon index) was not sufficient to assess the effect of the complexity of the community on productivity (Morin et al. 2011; Zhang et al. 2012).

First, trait-based functional diversity indices can be better predictors of productivity than species richness (Cadotte et al. 2011; Roscher et al. 2012) and may help bring to light the mechanisms that underpin the positive influence of biodiversity on productivity (Vilà et al. 2007; Cardinale et al. 2011; Mason et al. 2012). Species complementarity in resource use could be identified by a positive effect of the diversity of traits related to resource use on productivity (Díaz and Cabido 2001; Roscher et al. 2012). For instance, according to a meta-analysis by Zhang et al. (2012), the diversity of light use strategies in forests is positively related to its productivity. However, few studies have analyzed these effects of functional diversity and there is no consensus on which traits or which dimension of ecological strategies is the most determinant for forest productivity.

Secondly, studies in forest ecosystems have recently explored how tree size diversity in the stand (hereafter referred to as tree size inequality) mediate the effect of tree species richness on productivity. For instance, using structural equation models, Zhang and Chen (2015) demonstrated that tree species diversity increases stand aboveground biomass through an increase of tree size inequality in Canadian boreal forests. This result was corroborated by Morin et al. (2011) in a long-term simulation study with 30 European tree species. However, studies that explored the direct effect of tree size inequality on stand productivity in multispecies forests show more contrasted results. Some studies found an increase of productivity when tree size inequality increased (Lei et al. 2009; Hardiman et al. 2011; Dănescu et al. 2016; Silva Pedro et al. 2017; Zeller et al. 2018 for USA), while other studies found neutral or even negative effects (Liang et al.2007; Bohn and Huth 2017; Zeller et al. 2018 for Germany) of tree size inequality, in line with results obtained in monospecific stands (Ryan et al. 2010; Long and Shaw 2010; Cordonnier and Kunstler 2015; Soares et al. 2016; Bourdier et al. 2016). For instance, Liang et al. (2007) showed that basal area growth was negatively correlated with tree size inequality in Douglas fir-western hemlock mixtures as well as in mixed conifer forests.

These contrasting results reinforce the need for studies that evaluate the combined effect of tree species diversity, tree size inequality and tree functional diversity on stand productivity. Several authors (Pretzsch 2005; Morin et al. 2011; Zhang et al. 2012; Forrester 2013) pointed out that one potential way of reconciling these contrasting results is to explore whether or not tree size inequality interacts with functional composition (focusing on light use strategies) to control stand productivity. As discussed by (Kelty et al. 1992), stands with shade-tolerant species in the understory and shade-intolerant species in the upper canopy should have higher productivity than stands with the reverse structure. Several mechanisms related to the complementarity of resource use by species have been suggested to explain this potential effect: an increase in light interception (Pretzsch and Schütze 2016), higher light use efficiency (Kelty et al. 1992) and rapid mitigation of productivity losses by fast growth of more shade-tolerant species from lower canopy strata (Pretzsch 2003; Morin et al. 2011). Key in all these mechanisms is that shade-intolerant species must dominate in size shade-tolerant species, in other words, a negative covariance between shade tolerance and size should optimize stand productivity. However, to date, this potential effect of the covariance between size and shade tolerance on productivity has not been explicitly tested on a large set of species at a large scale.

Using 11,054 mixed-species plots from the French Forest Inventory database covering a wide range of bioclimatic conditions, we analyzed how stand productivity was influenced by tree species diversity, as well as tree size inequality, species shade tolerance diversity, and covariation between tree shade 
tolerance and size in the stand. More specifically, we tested if (i) species richness increased productivity, (ii) size inequality per se decreased productivity as in pure stands (e.g., Bourdier et al. 2016), (iii) shade tolerance diversity influenced productivity, and finally, (iv) a negative covariance between shade tolerance and size (shade-tolerant species preferentially in lower size classes) increased stand productivity.

This article is based on Bourdier (2016).

\section{Material and methods}

\subsection{Plot data}

We used plots from the French Forest Inventory (IGN) database (http://inventaire-forestier.ign.fr/spip/), which combine dendrometric and ecological data. These plots cover a large range of ecological conditions in France, and also cover managed and unmanaged forests located in private and public forests. Details on the IGN protocol can be found in Vallet and Pérot (2011), Wernsdörfer et al. (2012) and Bourdier et al. (2016, Appendix S1). It consists of a network of temporary plots established on a grid of $1000 \times 1000 \mathrm{~m}$ over all France. Each year, 10\% of the cells in this grid are sampled. Based on an annual square subsample design, a plot is randomly located in a square of $450 \mathrm{~m}$ around the center of the cell each time a particular grid node falls within a forested area. In each forest plot, dendrometric measurements are taken in three nested concentric circular subplots of different radii, based on circumference at breast height $(\mathrm{C} 130)$. All trees with $\mathrm{C} 130>23.5 \mathrm{~cm},>70.5 \mathrm{~cm}$, and $>117.5 \mathrm{~cm}$ are measured within a radius of $6 \mathrm{~m}, 9 \mathrm{~m}$, and $15 \mathrm{~m}$, respectively. For each measured tree, stem circumference, species, status (dead or alive, including only tree that died less than 5 years ago according to bark and small branches state), and radial increment over 5 years are recorded. The 5 years radial increment is determined from two cores taken at breast height. Among other ecological data, soil properties are characterized using a soil pit of up to $1 \mathrm{~m}$ depth located in the center of the plot. One or two soil horizons are distinguished from the soil pit, and depth, texture (based on eight classes) and coarse fragment content are recorded for each horizon.

A total of 39,865 plots distributed throughout France and inventoried once between 2006 and 2011 were available for this study. To limit perturbations and high heterogeneity in plots growth data, we excluded plots in coppice stands, plots where a cut had been applied in the last 5 years, plots located on forest margins, plots with a single tree (to avoid inflated values of the size inequality index), plots in plantations, plots where climatic data or growth data were not available. We also dropped 2708 plots including species with unknown shade tolerance indices. Finally, we excluded 3360 plots composed of only a single species because it is not relevant to explore the effect of the covariance between tree size and shade tolerance in mono-specific stands. Given that the diameter limit of $7.5 \mathrm{~cm}$ for tree measurement or the small area of the plots (15-m radius) can constrain values of the size inequality index (Gini index, see definition below) for low or high values of the quadratic mean diameter, we removed the plots corresponding to the upper and lower $5 \%$ percentile of the size inequality index and the quadratic mean diameter (2876 plots). We also removed 137 plots where species richness was greater than six species because we had too few observations for these levels of diversity. The final data set resulted in 11,054 plots.

For each plot, we estimated plot productivity as the basal area annual increment on the plot. The plot basal area is defined as the sum of individual tree basal areas, i.e. the cross section of their trunks at breast height $(1.30 \mathrm{~m})$. The mean basal area annual increment of each plot was calculated using the following equation adapted from Vallet and Pérot (2011):

$B A I=\frac{\Delta B A}{\Delta t}=\frac{1}{5} \sum_{i} \frac{10^{-4}}{4 \pi}\left(c_{130, i}^{2}-\left(c_{130, i}-2 \pi \times i r_{5, i}\right)^{2}\right) w_{i}$

with:

- $\quad \triangle B A\left(\mathrm{~m}^{2} \mathrm{ha}^{-1}\right)$ : plot basal area increment over 5 years;

- $\Delta t$ (years): 5-year growth period;

- $\quad c_{130, i}(\mathrm{~cm})$ : girth of tree $i$ at breast height $(1.30 \mathrm{~m})$;

- $\quad i r_{5, i}(\mathrm{~cm})$ : radial increment over 5 years of tree $i$ observed on an increment core;

- $\quad w_{i}\left(\right.$ trees.ha $\left.{ }^{-1}\right)$ : weight of tree $i$ for plot density estimation (taking into account subplot size and border effects).

Since 2009, only species and circumference have been measured on a number of trees called "simplified trees" to reduce field work for IGN teams. To estimate the radial increment of these trees ( $7.86 \%$ of trees in our data set), we used the average growth rate of the measured individual of the same species and same size class in a given plot (Appendix S1 in Bourdier et al. 2016). To estimate tree height of simplified tree, we fitted allometric functions between diameter at breast height and height for each species using the Gompertz equation and non-linear mixed models including species as a random effect in all parameters (Appendix 1).

To account for climatic variations across the sampling area, we calculated two variables that are known to influence growth (Kunstler et al. 2011): the sum of growing degree days (the sum of daily temperatures exceeding $5.56^{\circ} \mathrm{C}$, SGDD) and the annual soil water budget (WB) based on climatic and soil data. We used estimates of temperature, precipitation and solar radiation modeled and mapped throughout France by Piedallu et al. (Piedallu and Gégout 2008; Bertrand et al. 2011; Piedallu et al. 2013). We calculated the WB using the maximum soil 
water capacity estimated for each IGN plot using data (horizon textures, soil depth, coarse fragment content) from a soil pit (Piedallu et al. 2011), potential evapotranspiration (Turc 1961) and precipitation using the Bugmann and Cramer model (Bugmann and Cramer 1998).

\subsection{Quantifying tree size inequality: the Gini coefficient index}

Among indices used to characterize tree size inequality, the Gini coefficient index has been proven to have a greater discriminant ability of the stand structure and a lower sensitivity to sample size (Lexerød and Eid 2006; Valbuena et al. 2012). First developed in economics, it is now increasingly used in ecology to define tree size inequality (Klopcic and Boncina 2011; Valbuena et al. 2012; Cordonnier and Kunstler 2015; Pretzsch and Schütze 2016). Several authors (Lexerød and Eid 2006; Valbuena et al. 2012) suggested using this index instead of the classic Shannon index or other indices related to size distribution (e.g., coefficient of variation) that were used in the past (e.g., Liang et al. 2007; O'Hara et al. 2007; Gadow et al. 2012). Equations to compute the Gini index are available in Damgaard and Weiner (2000) and Duduman (2011). The Gini coefficient index ranges from 0 (perfect equality, where all values are the same) to 1 (maximum theoretical inequality). In our study, we applied the Gini index to individual tree heights (height inequality) as our objective was to characterize the hierarchy of trees within the canopy.

\subsection{Shade tolerance diversity and species diversity}

To account for shade tolerance in this study, we used Niinemets and Valladares' index of tree species shade tolerance (Niinemets and Valladares 2006) ranging from 1 (very intolerant) to 5 (very tolerant). We used two different metrics to characterize shade tolerance at the plot scale using basal area to account for species abundance: (i) the shade tolerance diversity using the FDis index (Laliberté and Legendre 2010) and (ii) the covariance between tree height and shade tolerance. The last index represents the size hierarchy between individual trees of varying shade tolerance: a positive value means that trees of shade-tolerant species are dominant in size, whereas a negative value means the reverse. The latter case was more common ( $72 \%$ of the plots) in our data set, as could be expected. The FDis index corresponds to the mean distance of individual species shade tolerance to the mean shade tolerance of all species in the plot weighted by their respective basal areas. To characterize tree species diversity, we used the tree species richness of each plot.

\subsection{Plot productivity analysis}

To analyze the effect of species richness, shade tolerance, and size inequality on plot productivity all things being equal, we took into account potential confounding effects caused by the variability of first-order plot structure characteristics and environmental conditions in our data set. To this end, we developed a model relating plot productivity (basal area increment BAI) to two major stand structural attributes and two environmental variables. We selected the total basal area (BA) to quantify growing stock, the mean plot quadratic diameter (QMD) to quantify development stage, and SGDD and WB as key environmental variables. To test our hypotheses, we also included species richness $(\mathrm{R})$ in the model, height inequality based on the Gini coefficient index (GINI), shade tolerance diversity based on the FDis index (FDIS), and finally the covariance between tree height and shade tolerance $(\mathrm{COV})$ to characterize the distribution of shade tolerance among size classes.

Previous studies have shown that the multiplicative model for the growth model (Bourdier et al. 2016) and the exponential model for the diversity effect (Cardinale et al. 2007) provided a good fit. Stand productivity was thus modeled as follows:

$$
\mathrm{BAI}=\left(a_{0} \mathrm{BA}^{a_{1}} e^{a_{2} \mathrm{BA}} e^{a_{3} \mathrm{QMD}}\right)\left(e^{b_{1} \mathrm{R}+b_{2} \mathrm{FDIS}+b_{3} \mathrm{GINI}+b_{4} \mathrm{COV}}\right)
$$

where $a_{0}$ is a linear combination of site effect and species composition such as:

$a_{0}=e^{\left(\alpha_{0}+\alpha_{1} \mathrm{WB}+\alpha_{2} \mathrm{SGDD}\right)+\left(\beta_{1} \mathrm{SP}_{1}+\beta_{2} \mathrm{SP}_{2}+\ldots+\beta_{n} \mathrm{SP}_{\mathrm{n}}\right)}$

where the first term represents the abiotic component that includes our two variables WB and SGDD based on climatic and soil data. The second term represents the species composition component where SPs are the proportion of each species on a plot. The species of frequency lower than $5 \%$ were grouped into shade-tolerant angiosperms, shade-intolerant angiosperms, shade-tolerant gymnosperms and shade-intolerant gymnosperms (the cutoff between shade-tolerance groups was defined as the median shade tolerance of the species pool). The species composition component in eq. (3) allowed us to account for species identity effects on productivity. The first term in eq. (2) represents the stand structure effect with basal area non-linear effects influencing productivity through both stocking and competition (Assmann 1970; we expect parameter $a_{2}$ to be negative). QMD effect is also included as it is considered an important factor for forest productivity (Vallet and Pérot 2011; Zeller et al. 2018). 


\subsection{Statistical analysis}

Based on IGN data, a linear regression was performed using the log-transformed version of the model (2). The $\log$ transformation of growth data has been applied in many studies (Appendix S2 in Bourdier et al. 2016) due to the classic log-normal distribution of basal area increments and is well suited for a multiplicative error structure. We assessed normality and heteroscedasticity visually using normal Q-Q plots and plots of residuals vs. predicted values (Figs. 5 and 6 in Appendix 2). Before performing linear regressions, we centered and standardized all independent variables related to climate, structure and diversity to facilitate the comparison of their effects on productivity. Based on Spearman correlation coefficients, we did not found any linear correlation above 0.31 between independent variables (except between basal area and its logarithm; Fig. 4 in Appendix 2). We conducted all statistical analyses using the $\mathrm{R}$ open-source software (Version 3.4, R Core Team). We used the functions $l m$, confint, and dropl to perform the regression, compute confidence intervals and determine loglikelihood ratio test of each factor.

\section{Results}

As expected, the three strongest effects on productivity were a positive effect of $\log$ basal area (LOG_BA: 0.39) and a negative effect of basal area (BA: -0.06$)$ reflecting a non-linear convex relationship between stand stocking and stand productivity, and a negative effect of the mean quadratic diameter (QMD: -0.18), which represents a development stage effect (Table 1 and Fig. 7 in Appendix 2). Species richness had a positive effect on productivity (R: 0.02 ; Fig. 1), whereas height inequality had a negative effect of higher magnitude (GINI: - 0.05). The covariance between height and shade tolerance had a significant negative effect on productivity (COV: $-0.01, p$ value: 0.024 ), showing that productivity decreases when tolerant species are dominant in height. Both environment variables had a positive effect on stand productivity, but the water budget had a much stronger impact (WB: 0.10) than the sum of growing degree days (SGDD: 0.02). Shade tolerance diversity showed no significant effect (FDIS, $p$ value $=$ $0.17)$.

An increase of species richness from two to six species (minimum and maximum richness in the data set) resulted in a $7.8 \%$ increase in productivity (Fig. 8 in Appendix 2). Height inequality influenced productivity with a higher effect size: an increase in height inequality from a Gini of 0.04 to 0.25 (quantiles 0.01 and 0.99 ) corresponded to an $18.9 \%$ decrease in productivity. The increase in covariance between height and

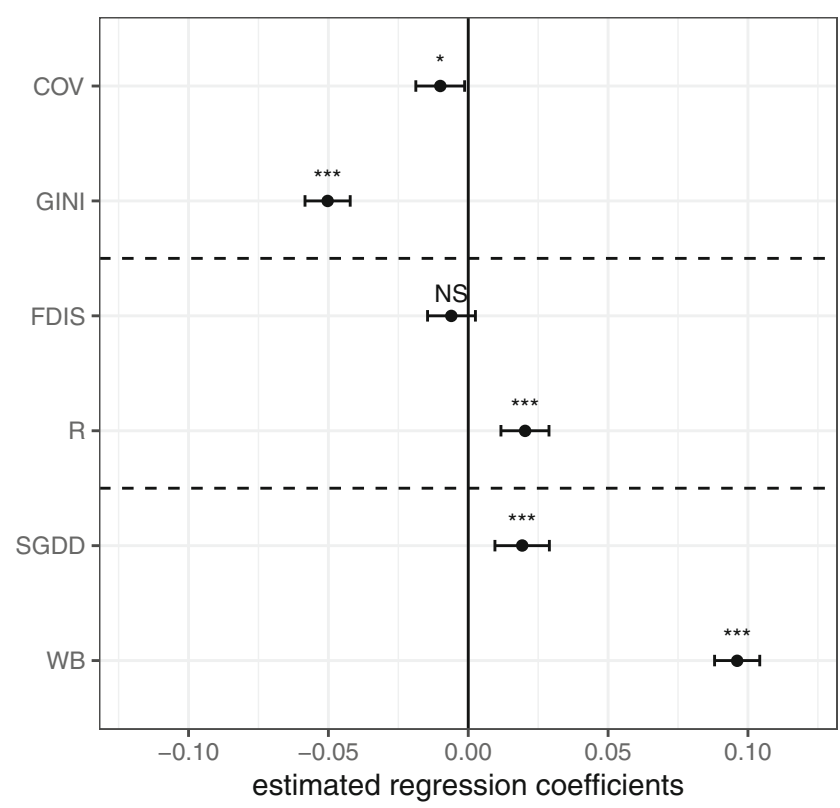

Fig. 1 Estimated linear regression coefficients of centered and standardized independent variables in the log-transformed version of model (2). The effects of LOG_BA (log of basal area), BA (basal area) and QMD (quadratic mean diameter) are not displayed in the figure for better visualization of the other variables' effects. The results are available in Appendix 2 for all variables (Table 1 and Fig. 7). Levels of significance are indicated on the graph based on a log-likelihood ratio test: (NS) $p$ value $>0.05,(*)<0.05,(* *)<0.01,(* * *)<0.001$. Error bars indicate the $95 \%$ confidence interval of estimated coefficients. COV: covariance between height and shade tolerance, GINI: height inequality, FDIS: shade tolerance diversity, R: species richness, WB: annual soil water budget, SGDD: sum of daily temperatures exceeding $5.56{ }^{\circ} \mathrm{C}$

shade tolerance from a negative $(-4.8)$ to a positive value (2.6) (quantiles 0.01 and 0.99 ) resulted in a $5.5 \%$ decrease in productivity.

\section{Discussion}

\subsection{A strong effect of stand characteristics and climate}

The two strongest effects in our study were attributed to stand variables related to stocking and stand development (basal area and mean quadratic diameter). This is in accordance with studies on large inventory data sets showing that stand basal area had a stronger effect on productivity than species richness (Paquette and Messier 2011; Vilà et al. 2013). Our model predicts a non-linear convex relationship between basal area and stand productivity, a pattern that has been reported in other studies and might reflect a balance between stocking and competition effects (Assmann 1970; Paquette and Messier 2011). The effect of stand development (here represented by the stand quadratic mean diameter QMD) on productivity was negative, which might be related to ontogenetic growth effects (Vallet and Pérot 2011). In line with recent studies (e.g., 
Zeller et al. 2018), our results underline the need to take into account these effects as a prerequisite for studies exploring the effect of more complex variables such as species diversity or tree size inequality. They also challenge the results obtained in studies that did not explicitly control for the stand development stage. Water budget was the stronger climatic predictor of stand productivity, which is coherent with previous studies using the same kind of data (Kunstler et al. 2009; Bourdier et al. 2016).

\subsection{Species richness effect}

This study confirmed the significant effect of species richness on productivity in agreement with previous studies (Paquette and Messier 2011; Morin et al. 2011; Zhang et al. 2012; Gamfeldt et al. 2013; Liang et al. 2016). In Swedish boreal forest ecosystems, Gamfeldt et al. (2013) found a considerable $50 \%$ increase of biomass production between pure plots and plots composed of five species. Two different recent analyses comparing monocultures to mixtures showed that mixed species stands were on average $24 \%$ more productive than the mean monocultures of the same species (Zhang et al. 2012; Vilà et al. 2013). Our results indicate a $8 \%$ increase, which is lower but still quite strong given that our study did not include monocultures and analyzed a limited range of two to six species. Previous studies reported a linear or exponential increase of productivity as species richness increased (Zhang et al. 2012; Gamfeldt et al. 2013; Vilà et al. 2013), up to six species where a plateau has generally been observed (Zhang et al. 2012), which agrees with our results.

\subsection{Size inequality effect}

Our results showed a significant negative effect of size inequality on productivity after controlling species diversity, stocking and stand development stage effects, which is in agreement with the results obtained by several authors in pure stands, through experimental, observational or more theoretical studies (Ryan et al. 2010; Caspersen et al. 2011; Cordonnier and Kunstler 2015; Soares et al. 2016; Bourdier et al. 2016). For instance, the negative effect of structural diversity can be as much as a $14 \%$ growth reduction in a young eucalyptus plantation (Ryan et al. 2010). In an analysis of pure stands, Bourdier et al. (2016) found a mean growth reduction of $7 \%$ across species (Gini index applied to tree basal areas) compared with the $18 \%$ in this study (Gini index applied to tree heights). In pure stands, a potential explanation for this negative effect of size inequality on productivity is that the benefit gained by dominant trees because of increased light interception is lower than the cost of reduced light interception for dominated trees (Ryan et al. 2010; Binkley et al. 2010). Bourdier et al. (2016) illustrated this mechanism by showing with a forest simulation model that size inequality in pure stands had a negative effect on both stand light interception efficiency and stand light use efficiency. In mixed species forest, several studies have also found a negative effect of size inequality on growth, either using modeling approaches (Liang et al. 2005; Caspersen et al. 2011; Bohn and Huth 2017) or observations in different forest types (Liang et al. 2007; Zeller et al. 2018 for Germany). Several authors suggested that this effect could differ according to forest types (Liang et al. 2007; Forrester and Bauhus 2016).

Other studies found positive relationships between size diversity and productivity (Lei et al. 2009; Dănescu et al. 2016; Silva Pedro et al. 2017). These contradictions between studies might in part be explained by methodological differences. First, different abiotic and biotic variables were controlled in these studies, which impedes comparisons. Second, the type of forest studied and species identity might also explain these differences as exemplified by the contrasted results obtained by Zeller et al. (2018) between Germany and USA. Third, the use of different plot sizes and different size diversity indices can also influence results on the size inequalityproductivity relationship (Dănescu et al. 2016; Bohn and Huth 2017). In a review of the processes driving diversityproductivity relationships, Forrester and Bauhus (2016) proposed that the effect of structural diversity might depend on the limiting resource: the effect would be beneficial for processes related to light but detrimental in stands where the limiting resource is not directly related to stand structure such as nutrient cycling. Overall, these findings indicate that more research is needed to study the relationship between structural diversity and productivity on varying contexts and forest types, exploring size inequality as well as other components of structural diversity such as the spatial arrangement of trees.

\subsection{Shade tolerance diversity effect}

Several authors considered the effect of shade tolerance diversity on productivity. For instance, Zhang et al. (2012) demonstrated that contrasting life-history traits greatly influenced productivity and that shade-tolerance variations within a community were responsible for most of this effect compared to other traits (i.e. N-fixation and growth habitat). Higher shade tolerance diversity was also proposed as a potential explanation for a positive species diversity effect on production in a long-term simulation study (Morin et al. 2011), but the mechanism proposed in that case is probably more closely related to regeneration than growth: advanced regeneration of shade-tolerant 
species prevented gaps from occurring in monospecific stands of shade-intolerant species. In contradiction with these findings, the shade tolerance diversity did not impact productivity in our study. Several hypotheses can be proposed to explain this lack of effect. First, we controlled the species identify effect in our model, whereas this was not always done in other studies. Second, the shade tolerance values we used were extracted from a global database (Niinemets and Valladares 2006); hence they might not be adapted to a local study.

\subsection{Covariance between size and shade tolerance}

Here we showed that integrating the distribution of traits and the distribution of sizes within a stand is crucial for a better understanding of diversity-productivity relationships. The magnitude of the effect of covariance between size inequality and shade tolerance was comparable to the positive effect of species richness. This result is in line with previous hypotheses (Kelty et al. 1992; SchererLorenzen et al. 2005) that proposed that the combination of shade-tolerant species in the understory with shadeintolerant species in the canopy could increase the global productivity of a forest stand. In a study disentangling size-symmetric and size-asymmetric competition, del Río et al. (2014) found evidence of complementarity effects in a two-species mixture, and in the few pairs of species analyzed this effect seems stronger for mixtures where a shade-intolerant species dominated a shade-tolerant species in size, in agreement with our results. This results could be explained by the fact that shade-intolerant species usually present low light interception efficiency associated with high light use efficiency, whereas shadetolerant species usually present high light interception efficiency associated with low light use efficiency (Messier et al. 1998; Lusk et al. 2008; Jucker et al. 2014). In our case, it means that when shade-intolerant species are in the upper strata and shade-tolerant species are in the lower strata, both are able to grow well.

\section{Conclusion}

Our study reinforced the consensus for a positive relationship between tree species richness and productivity. It also made a significant contribution to the growing debate on the effect of tree size inequality on productivity by demonstrating the importance of the hierarchy of shade tolerance among tree sizes. Our results have major implications for studies dealing with productivitybiodiversity relationships because they show that other factors than species richness (e.g., size inequality; covariance between shade tolerance and size) can influence productivity with the same order of magnitude. These results could indicate that failing to account for these effects can lead to biasing the estimate of the species diversity effect. Future studies on the effect of species diversity on productivity in forests need to explore how the size hierarchy of shade tolerance or other functional characteristics controls productivity and explore the mechanism underpinning this effect in greater detail.

Funding This article has been supported by the DISTIMACC project (BGF, no. Ecofor 2014-23) and the GIS-COOP "Cooperative for data on forest tree and stand growth". LESSEM is part of Labex OSUG@2020(ANR10 LABX56).

Data availability The French Forest Inventory (IGN) data that support the findings of this study are available on the following website: http:// inventaire-forestier.ign.fr/spip/. The method to estimate tree heights for simplified tree is available in Appendix 1. Restrictions apply to the availability of climate data and so are not publicly available. These data are however available from the authors upon reasonable request with permission of Christian Piedallu (INRA, UR SILVA).

\section{Compliance with ethical standards}

Conflict of interest The authors declare that they have no conflict of interest.

\section{Appendix 1 - Estimation of tree height for simplified trees}

\section{Introduction}

This appendix describes the estimation of tree height for simplified tree in the French Forest Inventory. The French Forest Inventory (see IGN website) data reports the height for a sample of the trees in each plot, while height is not measured for the remaining trees (simplified trees). We used this data to fit a hierarchical allometric model of tree height in function of diameter at breast height (dbh) where species was included as a random effect in the parameters. This allows estimating allometric tree height for species with few observations.

\section{Allometric model estimation}

We selected all species with more than 20 height measurements to estimate the model and for the remaining species we applied an average model. Then we fitted a hierarchical allometric model using JAGS (Plummer 2003) based on the equation of Caspersen et al. (2011):

$H_{i, s}=1.3+\left(B_{s}-1.3\right)\left(1-e^{\left(\frac{-A_{s}}{B_{s}-1.3} D_{i, s}\right)}\right)$ 
where $H_{i, s}$ and $D_{i, s}$ are respectively the height and dbh of individual $i$ of species $s$ and $A_{s}$ and $B_{s}$ are random species parameters drawn in normal distributions. The model allows predicting a height of $1.3 \mathrm{~m}$ for a dbh of zero. The
JAGS code used is given below. We fitted the model using jagsJAGS with non-informative priors and checked the convergence with the Gelman-Rubin convergence diagnostic $\hat{R}$ computed on three chains $(\hat{R}<1.1)$ (Fig. 2).
Fig. 2 Example of height $v s$. dbh allometric models fitted for four species. Models were fitted with the eq. 1 and a random species effect

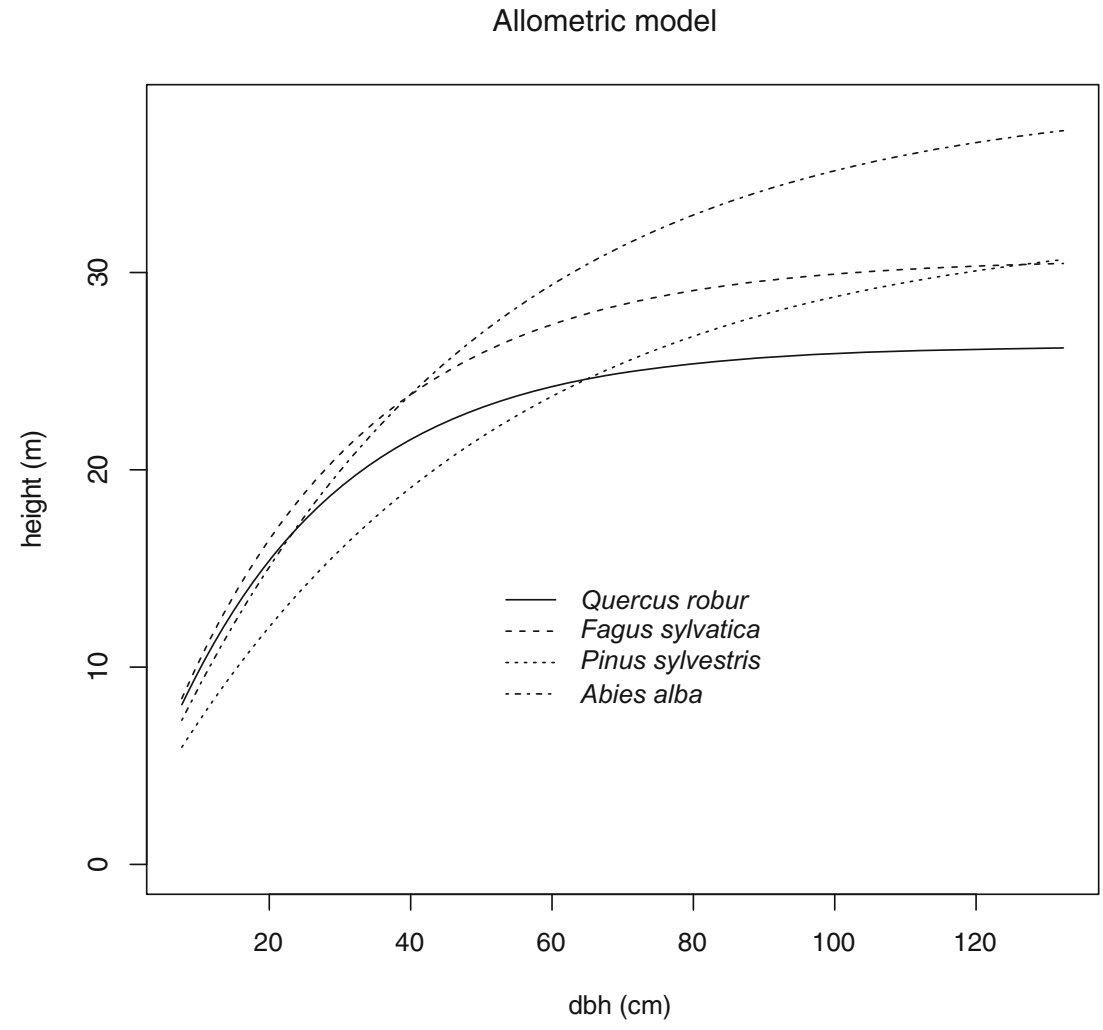




\section{$R$ and JAGS code}

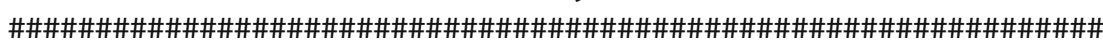
\# Fit Canham allometric model MODEL modified by Caspersen et al. 2011 in JAGS

\#\# load library

library(R2jags)

\#\# DATA to fit allometric models

\#\#

\#\# data is the data.frame with only raws with non NA for height

\#\# with the following variables

\#\# data\$htot height in $\mathrm{m}$

\#\# data\$dbh dbh in $\mathrm{cm}$

\#\# data\$espar species code

\#\#\# JAGS script

ALLO.MODEL <-

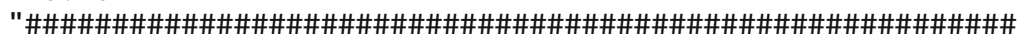

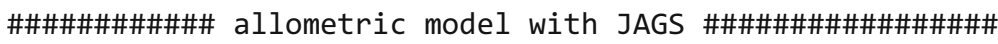
model \{

\#\#\#\#\#\#\#\#\#\#\# Likelihood \#\#\#\#\#\#\#\#\#\#\#\#\#\#\#\#

for ( $i$ in 1:N.indiv) \{ htot [i] dnorm(theo.htot [i], tau) theo.htot $[i]<-$

$1.3+(B 1[\operatorname{species}[i]]-1.3) *(1-\exp (-$

$B 2[$ species $[i]] /(B 1[\operatorname{species}[i]]-1.3) * d b h[i]))$

\}

\#\#\#\#\#\#\#\#\#\# Hierarchical parameters \#\#\#\#\#\#\#

for ( $n$ in $1:$ NSP)

\{

$B 1[n] \sim \operatorname{dnorm}(\operatorname{muBB}[1]$, pow (sigma.b1, -2))

\}

$B 2[\mathrm{n}] \sim \operatorname{dnorm}(\operatorname{muBB}[2]$, pow (sigma.b2, -2$)$ )

\#\#\#\#\#\#\#\#\# Non-hierarchical parameters \#\#\#\#\#\#\#

tau dgamma $(0.001,0.001)$

sigma.b1 dunif $(0.001,3)$

sigma.b2 dunif $(0.001,0.2)$

$\operatorname{muBB}[2] \sim \operatorname{dnorm}(\operatorname{muBB} 0[2], 1) \mathrm{T}(0.1,4)$

$\operatorname{muBB}[1] \sim \operatorname{dnorm}(\operatorname{muBB} 0[1], 0.2 \mathrm{E}-1) \mathrm{T}(1.3$,

\} \# End of the jags model

$\operatorname{cat}($ ALLO.MODEL, file = "ALLO.MODEL", sep=" ",

fill = FALSE, labels = NULL, append = FALSE)

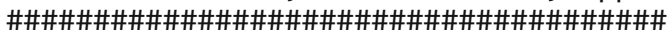

\#\#\#\#\#\# Format data for JAGS \#\#\#\#\#\#\#\#

muBB0 <- $c(35,1.3)$ \# mean of informative prior

htot <- (data\$htot)

dbh $<-($ data $\$$ c13/dbh $)$

species <- unclass (factor(data\$espar))

NSP <- length(unique(species))

N.indiv <- length(htot)

jags.data<-list("htot", "dbh", "N.indiv", "NSP", "muBB0", "species")

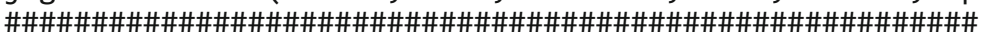

\#\#\#\# INITIAL VALUES

jags.inits <- function( $)\{$

list $(" \operatorname{muBB} "=c(\operatorname{runif}(1, \min =20, \max =40), \operatorname{runif}(1, \min =0.5, \max =2)))$ \}

\#\#\# SEND to jags

\#\# parallel version

ALLO.C <- jags.parallel(data=jags.data,

values

inits=jags.inits, \# We precise data and starting

model.file = "ALLO.MODEL", \# Model file name

parameters.to.save =c("B1", "B2", "muBB",

"tau", "sigma.b1", "sigma.b2"),

n. chains $=3, \mathrm{n}$. cluster $=3$, \# Number of chains

n. iter $=3000, n$. burnin=500, n.thin $=3$ )

\#\# check convergence

(ALLO.C\$BUGSoutput\$summary) [(ALLO.C\$BUGSoutput\$summary $[, 8])>1.1,8]$ 


\section{Appendix 2 - Results of the linear model relating basal area increment to stand and environmental characteristics}

\section{Introduction}

This appendix provides the distributions of independent variables, the correlations between independent variables and the results of the linear regression analysis for the log-transformed version of model (2). It also provides the figures to evaluate the model fit and underlying assumptions (standardized residuals vs. predicted values, observed vs. predicted values, QQ-plot) and the effects of variables related to diversity (height, shade tolerance, species) and environment on the stand basal area increment. with.

$\begin{array}{ll}\text { BAI } & \text { Basal area increment }\left(\mathrm{m}^{2} \mathrm{ha}^{-1} \mathrm{year}^{-1}\right) \\ \text { WB } & \text { Annual soil water budget }(\mathrm{mm}) \\ \text { SGDD } & \text { Sum of daily temperatures exceeding } 5.56{ }^{\circ} \mathrm{C}\left({ }^{\circ} \mathrm{C}\right) \\ \text { BA } & \text { Basal area }\left(\mathrm{m}^{2} \mathrm{ha}^{-1}\right) \\ \text { QMD } & \text { Quadratic mean diameter }(\mathrm{m}) \\ \text { R } & \text { Species richness }(-) \\ \text { FDIS } & \text { Shade tolerance diversity }(-) \\ \text { GINI } & \text { Height inequality }(-) \\ \text { COV } & \text { Covariance between height and shade tolerance }(\mathrm{m}) \\ \varepsilon & \text { normal error }\end{array}$

We have $\log \left(\beta_{0}\right)=\beta_{1} \mathrm{SP}_{1}+\beta_{2} \mathrm{SP}_{2}+\ldots+\beta_{20} \mathrm{SP}_{20}$ with $\mathrm{SP}_{i}$ the proportion of the species (or species group) $i$.

\section{The model}

The log-transformed version of the model (2) is the following:

$\log (\mathrm{BAI})=\log \left(\beta_{0}\right)+\alpha_{1} \mathrm{WB}+\alpha_{2} \mathrm{SGDD}+a_{1} \log (\mathrm{BA})+a_{2} \mathrm{BA}$

$$
+a_{3} \mathrm{QMD}+b_{1} \mathrm{R}+b_{2} \mathrm{FDIS}+b_{3} \mathrm{GINI}+b_{4} \mathrm{COV}+\varepsilon
$$
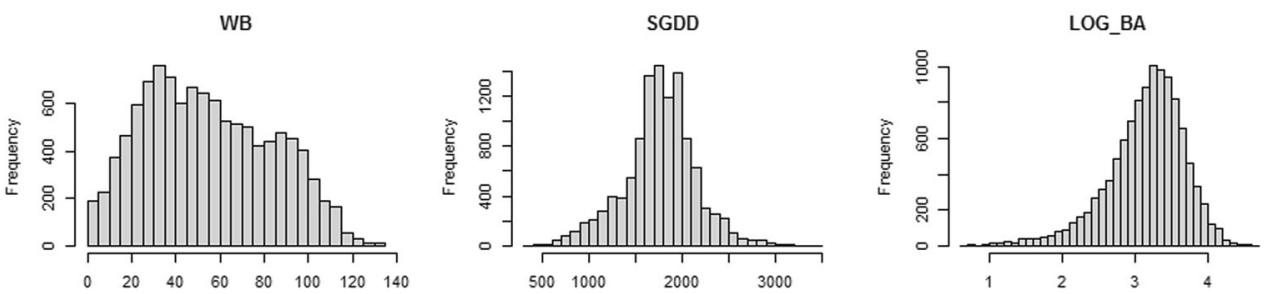

QMD
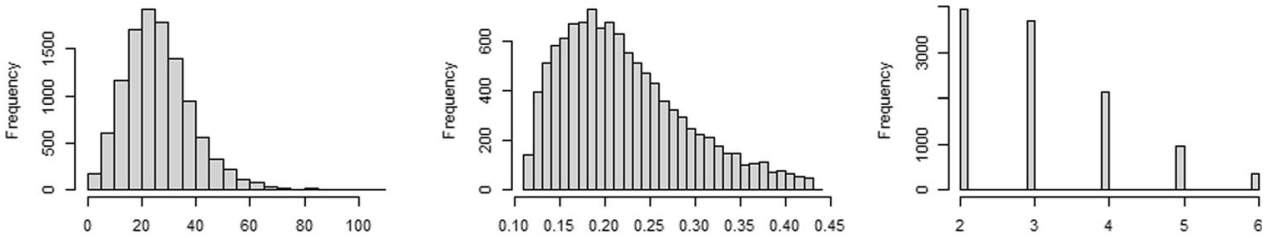

FDIS
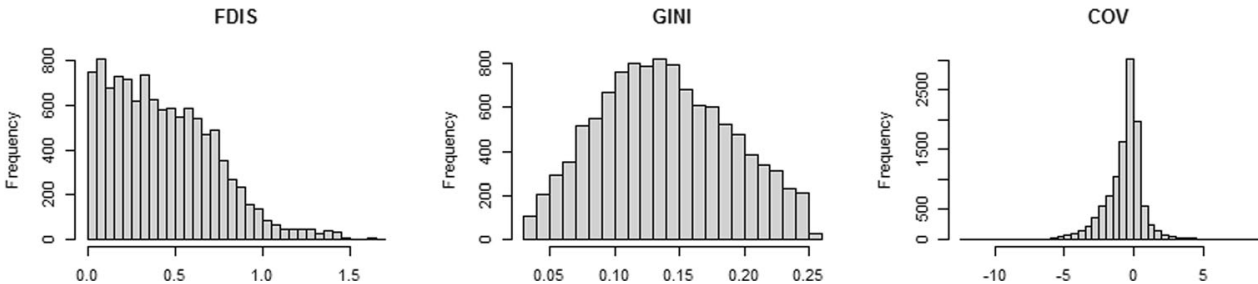

Fig. 3 Distributions of independent variables. WB: annual soil water budget, SGDD: sum of daily temperatures exceeding $5.56{ }^{\circ} \mathrm{C}, \mathrm{LOG}_{-}$ BA: log of basal area, BA: basal area, QMD: quadratic mean diameter,

R: species richness, FDIS: shade tolerance diversity, GINI: height inequality, COV: covariance between height and shade tolerance 
Fig. 4 Pearson correlation coefficients between independent variables. WB: annual soil water budget, SGDD: sum of daily temperatures exceeding $5.56^{\circ} \mathrm{C}$, LOG_BA: log of basal area, BA: basal area, QMD: quadratic mean diameter, R: species richness, FDIS: shade tolerance diversity, GINI: height inequality, COV: covariance between height and shade tolerance

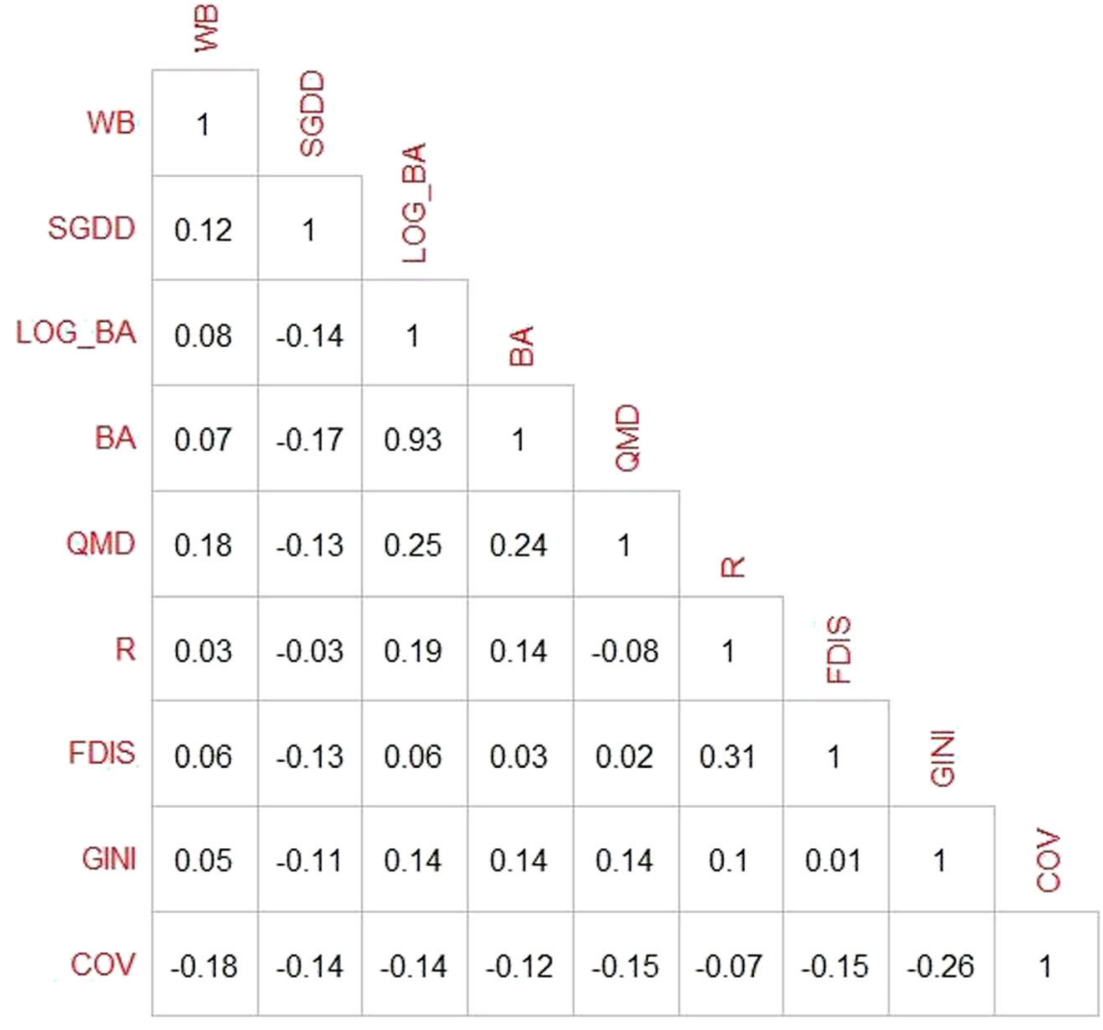

Table 1 Summary of results obtained for the linear model using the $l m$ function in R (3.4); $p$ values are based on loglikelihood ratio tests using the dropl function. Independent variables related to climate, structure and diversity were centred and standardized before the regression analysis. WB: annual soil water budget, SGDD: sum of daily temperatures exceeding $5.56{ }^{\circ} \mathrm{C}$, LOG_BA: $\log$ of basal area, BA: basal area, QMD: quadratic mean diameter, R: species richness, FDIS: shade tolerance diversity, GINI: height inequality, COV: covariance between height and shade tolerance

\begin{tabular}{|c|c|c|c|c|c|}
\hline Factor & Estimate & Std. error & $p$ value & $2.5 \%$ & $97.5 \%$ \\
\hline Quercus robur L. & -0.713 & 0.015 & $<0.001$ & -0.743 & -0.683 \\
\hline Quercus petraea (Matt.) Liebl. & -0.820 & 0.014 & $<0.001$ & -0.847 & -0.793 \\
\hline Quercus pubescens Willd. & -1.232 & 0.021 & $<0.001$ & -1.273 & -1.192 \\
\hline Fagus sylvatica $\mathrm{L}$. & -0.672 & 0.017 & $<0.001$ & -0.706 & -0.638 \\
\hline Castanea sativa Mill. & -0.403 & 0.023 & $<0.001$ & -0.449 & -0.358 \\
\hline Carpinus betulus L. & -0.705 & 0.021 & $<0.001$ & -0.746 & -0.664 \\
\hline Betula pendula Roth & -0.343 & 0.035 & $<0.001$ & -0.411 & -0.275 \\
\hline Acer pseudoplatanus $\mathrm{L}$. & -0.133 & 0.052 & 0.011 & -0.235 & -0.031 \\
\hline Fraxinus excelsior $\mathrm{L}$. & -0.475 & 0.029 & $<0.001$ & -0.532 & -0.418 \\
\hline Acer campestre L. & -0.689 & 0.060 & $<0.001$ & -0.807 & -0.571 \\
\hline Prunus avium (L.) L. & -0.287 & 0.069 & $<0.001$ & -0.422 & -0.152 \\
\hline Populus tremuloides Michx. & -0.186 & 0.049 & $<0.001$ & -0.282 & -0.089 \\
\hline Corylus avellana L. & -0.611 & 0.085 & $<0.001$ & -0.777 & -0.444 \\
\hline Pinus sylvestris L. & -0.807 & 0.017 & $<0.001$ & -0.839 & -0.774 \\
\hline Abies alba Mill. & -0.106 & 0.025 & $<0.001$ & -0.156 & -0.057 \\
\hline Picea abies (L.) H.Karst. & -0.165 & 0.033 & $<0.001$ & -0.230 & -0.099 \\
\hline Gymnosperm tolerant & 0.313 & 0.135 & 0.020 & 0.049 & 0.576 \\
\hline Gymnosperm intolerant & -0.779 & 0.025 & $<0.001$ & -0.828 & -0.730 \\
\hline Angiosperm tolerant & -0.827 & 0.026 & $<0.001$ & -0.877 & -0.777 \\
\hline Angiosperm intolerant & -0.375 & 0.033 & $<0.001$ & -0.441 & -0.309 \\
\hline WB & 0.096 & 0.004 & $<0.001$ & 0.088 & 0.104 \\
\hline SGDD & 0.019 & 0.005 & $<0.001$ & 0.010 & 0.029 \\
\hline LOG BA & 0.392 & 0.011 & $<0.001$ & 0.371 & 0.413 \\
\hline BA & -0.063 & 0.011 & $<0.001$ & -0.084 & -0.042 \\
\hline QMD & -0.177 & 0.004 & $<0.001$ & -0.186 & -0.169 \\
\hline $\mathrm{R}$ & 0.020 & 0.004 & $<0.001$ & 0.012 & 0.029 \\
\hline FDIS & -0.006 & 0.004 & 0.170 & -0.015 & 0.003 \\
\hline GINI & -0.050 & 0.004 & $<0.001$ & -0.058 & -0.042 \\
\hline $\mathrm{COV}$ & -0.010 & 0.004 & 0.024 & -0.019 & -0.001 \\
\hline
\end{tabular}



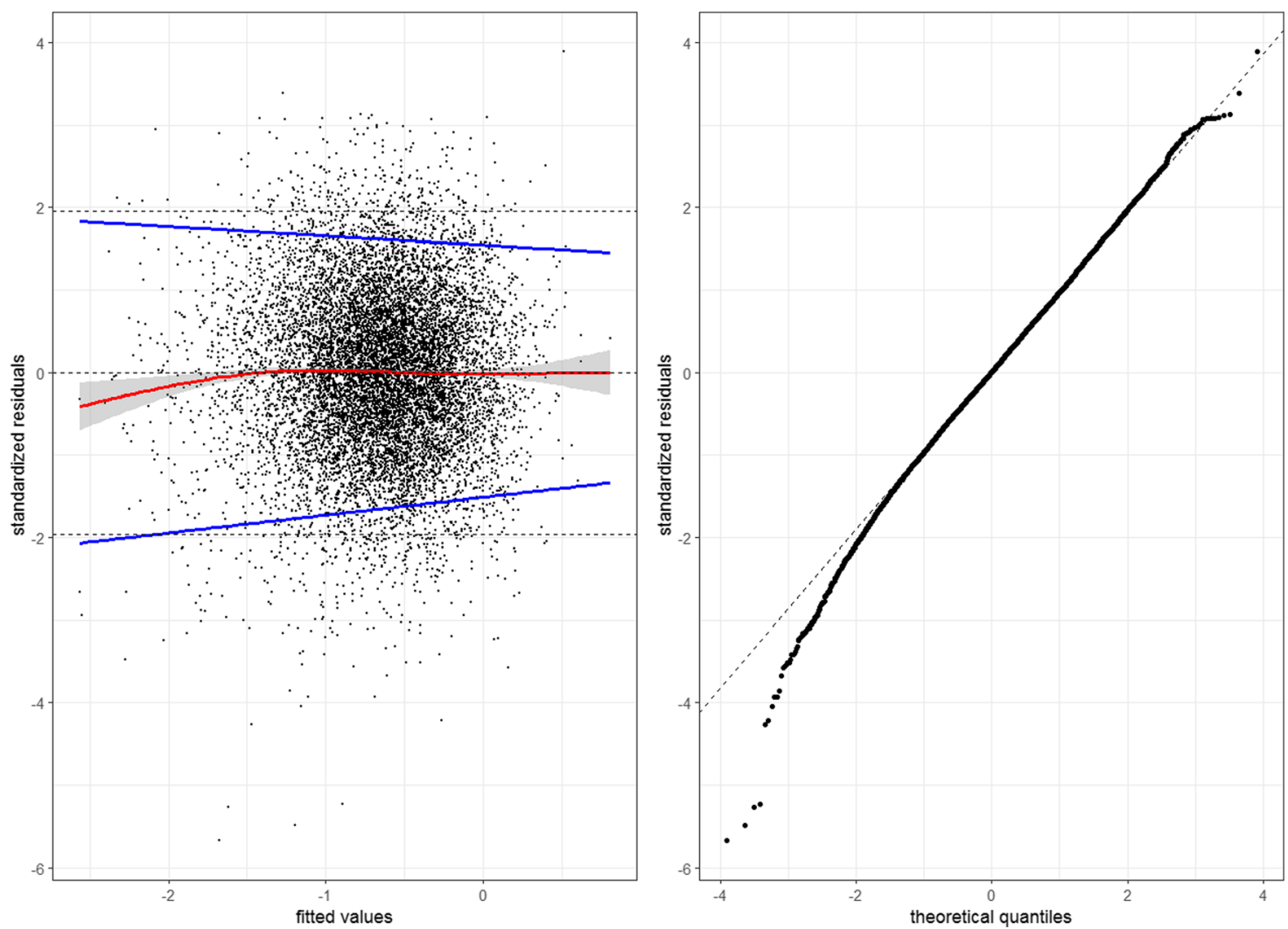

Fig. 5 Plot of observed standardized residuals vs. fitted values and QQ-plot of standardized residuals. The red line represents a gam regression with its confident interval; dotted lines indicate $0,1.96$, and -1.96 values of residuals; the blue lines represent quantiles regressions (quantiles 0.05 and 0.95 )

Fig. 6 Observed values vs. predicted values. The solid line represents the 1/1 linear relationship

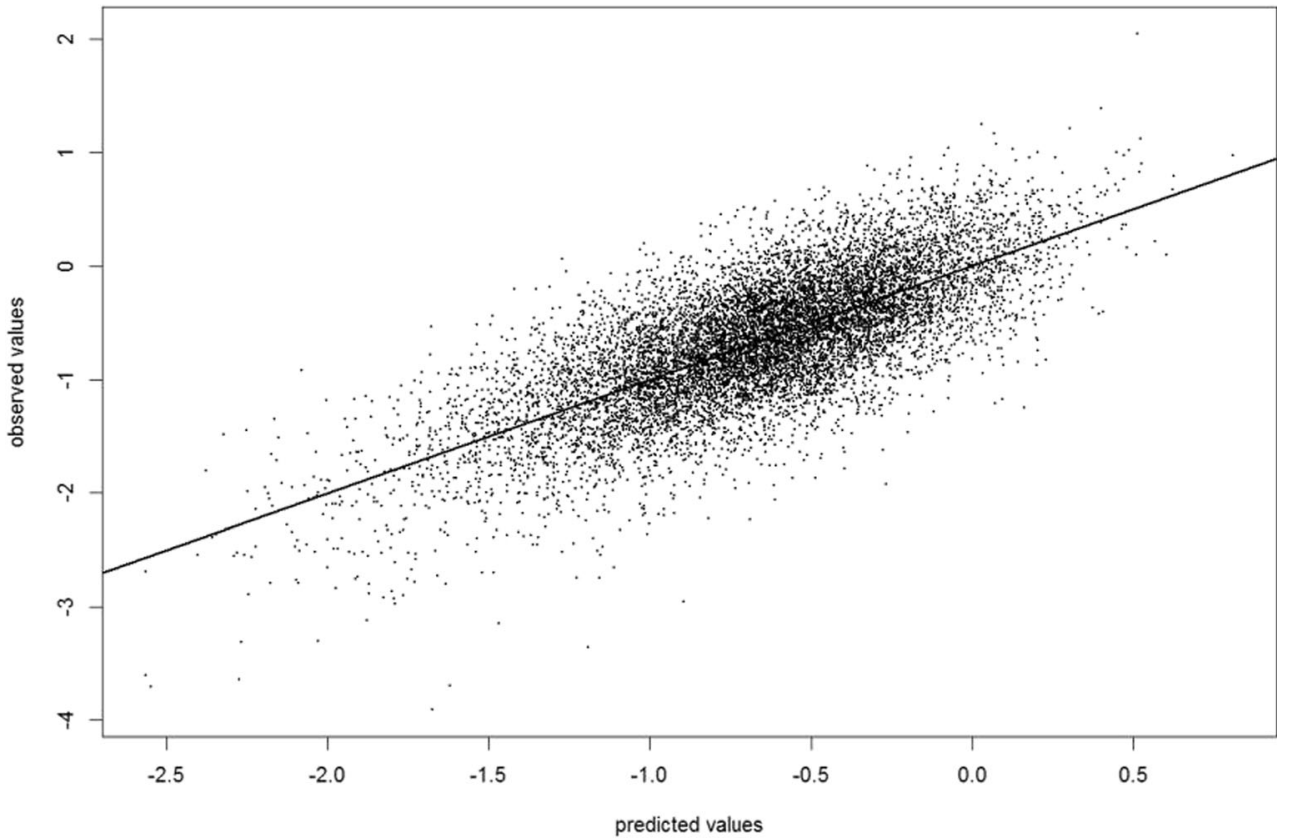


Fig. 7 Estimated regression coefficients for centered and standardized BA (basal area), LOG_BA (log of basal area) and QMD (quadratic mean diameter). Levels of significance are indicated on the graph based on a log-likelihood ratio test: (NS) $p$ value $>0.05,(*)<0.05,(* *)<$ $0.01,(* * *)<0.001$. Error bars indicate the $95 \%$ confidence interval of estimated coefficients

Fig. 8 Percentage of variation of BAI when independent variable varies from their quantile 0.01 to their quantile 0.99 (numbers above or below bars). Only significant variables related to diversity (height, shade tolerance, species) and environment are shown. COV: covariance between height and shade tolerance, GINI: height inequality, R: species richness, SGDD: sum of daily temperatures exceeding $5.56^{\circ} \mathrm{C}$, WB: annual soil water budget

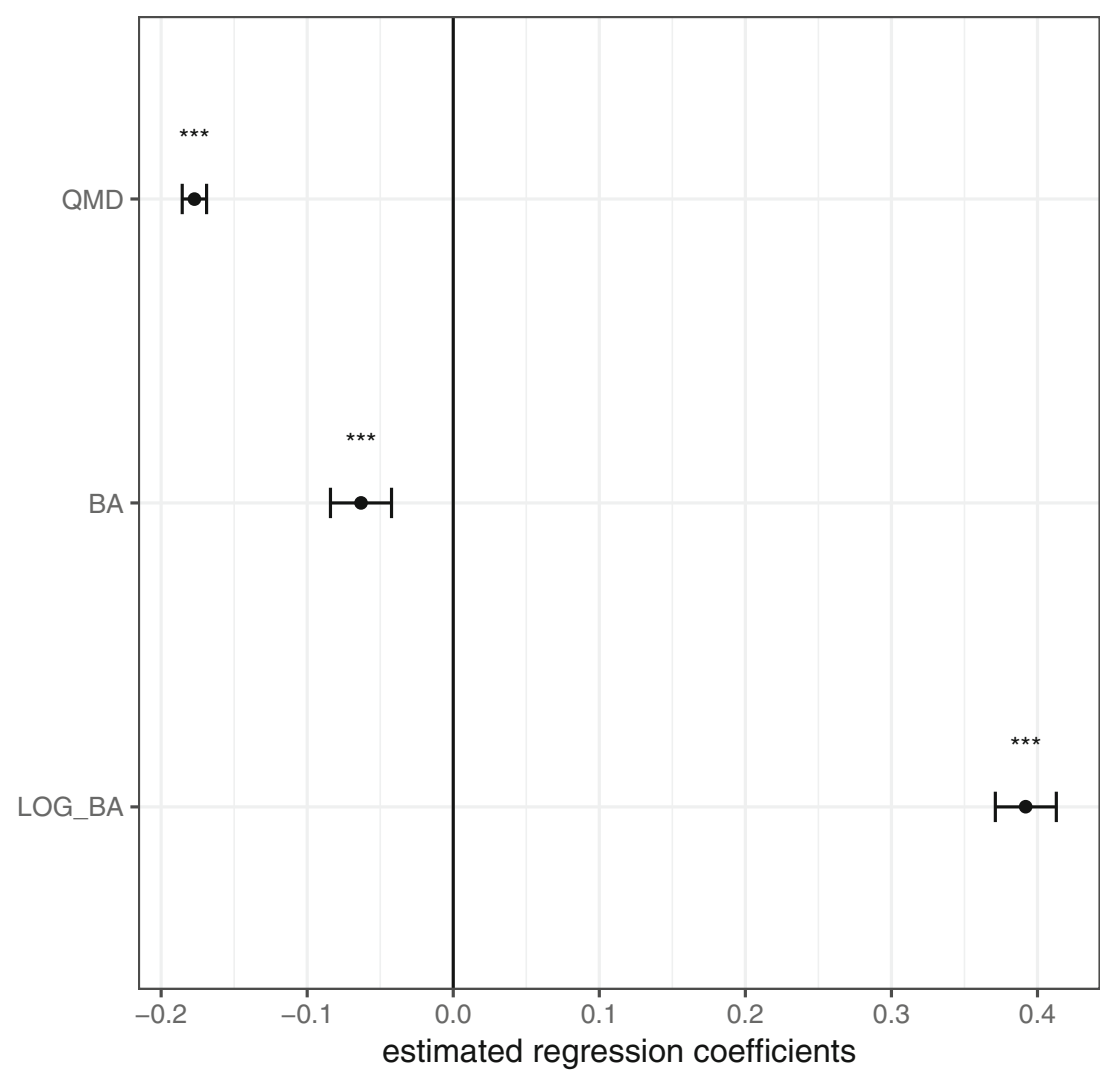

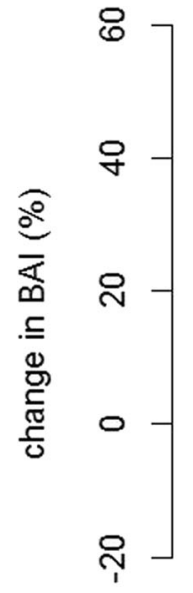

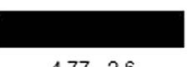

$-4.77-2.6$

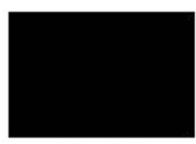

$0.04-0.25$
$2.71-114.68$

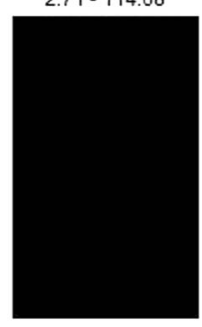

$760.39-2741.21$
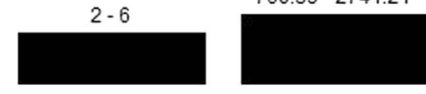
$\mathrm{R}$
GINI
SGDD
WB
COV

.

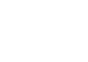




\section{References}

Assmann E (1970) The principles of forest yield study. Studies in the organic production, structure, increment and yield of forest stands $510 \mathrm{p}$

Bertrand R, Lenoir J, Piedallu C, Riofrío-Dillon G, de Ruffray P, Vidal C, Pierrat JC, Gégout JC (2011) Changes in plant community composition lag behind climate warming in lowland forests. Nature 479: $517-520$

Binkley D, Stape JL, Bauerle WL, Ryan MG (2010) Explaining growth of individual trees: light interception and efficiency of light use by Eucalyptus at four sites in Brazil. For Ecol Manag 259:1704-1713

Bohn FJ, Huth A (2017) The importance of forest structure to biodiversity-productivity relationships. Royal Society Open Science 4

Bourdier T (2016) Hétérogénéité des peuplements forestiers et production: interactions avec les traits fonctionnels des espèces. $\mathrm{PhD}$ Thesis, Université Grenoble Alpes. <NNT:2016GREAV050>. $<$ tel-01684683>. https://tel.archives-ouvertes.fr/tel-01684683

Bourdier T, Cordonnier T, Kunstler G, Piedallu C, Lagarrigues G, Courbaud B (2016) Tree size inequality reduces forest productivity: an analysis combining inventory data for ten European species and a light competition model. PLoS One 11:e151852

Bugmann H, Cramer W (1998) Improving the behaviour of forest gap models along drought gradients. For Ecol Manag 103:247-263

Cadotte MW, Carscadden K, Mirotchnick N (2011) Beyond species: functional diversity and the maintenance of ecological processes and services. J Appl Ecol 48:1079-1087

Cardinale BJ, Wright JP, Cadotte MW, Carroll IT, Hector A, Srivastava DS, Loreau M, Weis JJ (2007) Impacts of plant diversity on biomass production increase through time because of species complementarity. Proc Nat Acad Sci USA 104(46):18123-18128

Cardinale BJ, Matulich KL, Hooper DU, Byrnes JE, Duffy E, Gamfeldt L, Balvanera P, O'Connor MI, Gonzalez A (2011) The functional role of producer diversity in ecosystems. Am J Bot 98:572-592

Cardinale BJ, Duffy JE, Gonzalez A, Hooper DU, Perrings C, Venail P, Narwani A, Mace GM, Tilman D, Wardle DA, Kinzig AP, Daily GC, Loreau M, Grace JB, Larigauderie A, Srivastava DS, Naeem S (2012) Biodiversity loss and its impact on humanity. Nature 486:5967

Caspersen JP, Vanderwel MC, Cole WG, Purves DW (2011) How stand productivity results from size- and competition-dependent growth and mortality. PLoS ONE 6(12):e28660

Cordonnier T, Kunstler G (2015) The Gini index brings asymmetric competition to light. Perspect Plant Ecol Evol Syst 17:1-9

Damgaard C, Weiner J (2000) Describing inequality in plant size or fecundity. Ecology 81:1139-1142

Dănescu A, Albrecht AT, Bauhus J (2016) Structural diversity promotes productivity of mixed, uneven-aged forests in southwestern Germany. Oecologia 4:319-341

del Río M, Condés S, Pretzsch H (2014) Analyzing size-symmetric vs. size-asymmetric and intra- vs. inter-specific competition in beech (Fagus sylvatica L.) mixed stands. For Ecol Manag 325:90-98

Díaz S, Cabido M (2001) Vive la différence: plant functional diversity matters to ecosystem processes. Trends Ecol Evol 16:646-655

Duduman G (2011) A forest management planning tool to create highly diverse uneven-aged stands. Forestry 84(3):301-314

Duffy JE, Godwin CM, Cardinale BJ (2017) Biodiversity effects in the wild are common and as strong as key drivers of productivity. Nature 549:261-264

Farnsworth KD, Albantakis L, Caruso T (2017) Unifying concepts of biological function from molecules to ecosystems. Oikos 126: $1367-1376$
Forrester DI (2013) The spatial and temporal dynamics of species interactions in mixed-species forests: from pattern to process. For Ecol Manag 312:282-292

Forrester DI, Bauhus J (2016) A review of processes behind diversityproductivity relationships in forests. Curr Forestry Rep 2:45-61

Gadow K, Zhang CY, Wehenkel C, Pommerening A, Corral-rivas J, Korol M, Myklush S, Hui GY, Kiviste A, Zhao XH (2012) Forest structure and diversity. In: Pukkala T, von Gadow K (eds) Continuous cover forestry. Springer Netherlands, Dordrecht, pp 29-83

Gamfeldt L, Snäll T, Bagchi R, Jonsson M, Gustafsson L, Kjellander P, Ruiz-Jaen MC, Fröberg M, Stendahl J, Philipson CD, Mikusiński G, Andersson E, Westerlund B, Andrén H, Moberg F, Moen J, Bengtsson J (2013) Higher levels of multiple ecosystem services are found in forests with more tree species. Nat Commun 4:1340

Grace JB, Anderson TM, Seabloom EW, Borer ET, Adler PB, Harpole WS, Hautier Y, Hillebrand H, Lind EM, Pärtel M, Bakker JD, Buckley YM, Crawley MJ, Damschen EI, Davies KF, Fay PA, Firn J, Gruner DS, Hector A, Knops JMH, MacDougall AS, Melbourne BA, Morgan JW, Orrock JL, Prober SM, Smith MD (2016) Integrative modelling reveals mechanisms linking productivity and plant species richness. Nature 529(7586):390-393

Hardiman BS, Bohrer G, Gough CM, Vogel CS, Curtisi PS (2011) The role of canopy structural complexity in wood net primary production of a maturing northern deciduous forest. Ecology 92:1818-1827

Huston MA (2000) No consistent effect of plant diversity on productivity. Science 289:1255a

Jucker T, Bouriaud O, Avacaritei D, Coomes DA (2014) Stabilizing effects of diversity on aboveground wood production in forest ecosystems: linking patterns and processes. Ecol Lett 17:1560-1569

Kelty MJ, Larson BC, Oliver CD (1992) The ecology and silviculture of mixed-species forests. Kluwer Academic Publishers, Dordrecht

Klopcic M, Boncina A (2011) Stand dynamics of silver fir (Abies alba mill.) -European beech (Fagus sylvatica L.) forests during the past century: a decline of silver fir? Forestry 84:259-271

Kunstler G, Coomes DA, Canham CD (2009) Size-dependence of growth and mortality influence the shade tolerance of trees in a lowland temperate rain forest. J Ecol 97:685-695

Kunstler G, Albert CH, Courbaud B, Lavergne S, Thuiller W, Vieilledent G, Zimmermann NE, Coomes DA (2011) Effects of competition on tree radial-growth vary in importance but not in intensity along climatic gradients. J Ecol 99:300-312

Laliberté E, Legendre P (2010) A distance-based framework for measuring functional diversity from multiple traits. Ecology 91:299-305

Lei X, Wang W, Peng C (2009) Relationships between stand growth and structural diversity in spruce-dominated forests in New Brunswick, Canada. Can J For Res 39:1835-1847

Lexerød NL, Eid T (2006) An evaluation of different diameter diversity indices based on criteria related to forest management planning. For Ecol Manag 222:17-28

Liang J, Buongiorno J, Monserud RA (2005) Growth and yield of allaged Douglas-fir - western hemlock forest stands: a matrix model with stand diversity effects. Can J For Res 35:2368-2381

Liang J, Buongiorno J, Monserud RA, Kruger EL, Zhou M (2007) Effects of diversity of tree species and size on forest basal area growth, recruitment, and mortality. For Ecol Manag 243:116-127

Liang J et al (2016) Positive biodiversity-productivity relationship predominant in global forests. Science 354:aaf8957

Long JN, Shaw JD (2010) The influence of compositional and structural diversity on forest productivity. Forestry 83:121-128

Lusk CH, Reich PB, Montgomery RA, Ackerly DD, Cavender-Bares J (2008) Why are evergreen leaves so contrary about shade? Trends Ecol Evol 23:299-303

Mason NWH, de Bello F, Mouillot D, Pavoine S, Dray S (2012) A guide for using functional diversity indices to reveal changes in assembly processes along ecological gradients. J Veg Sci 24:794-806 
Messier C, Parent S, Bergeron Y (1998) Effects of overstory and understory vegetation on the understory light environment in mixed boreal forests. J Veg Sci 9:511-520

Morin X, Fahse L, Scherer-Lorenzen M, Bugmann H (2011) Tree species richness promotes productivity in temperate forests through strong complementarity between species. Ecol Lett 14:1211-1219

Niinemets Ü, Valladares F (2006) Tolerance to shade, drought, and waterlogging of temperate northern hemisphere trees and shrubs. Ecol Monogr 76:521-547

O'Hara KL, Hasenauer H, Kindermann G (2007) Sustainability in multiaged stands: an analysis of long-term plenter systems. Forestry 80: 163-181

Paquette A, Messier C (2011) The effect of biodiversity on tree productivity: from temperate to boreal forests. Glob Ecol Biogeogr 20:170 180

Piedallu C, Gégout JC (2008) Efficient assessment of topographic solar radiation to improve plant distribution models. Agric For Meteorol 148:1696-1706

Piedallu C, Gégout J-C, Bruand A, Seynave I (2011) Mapping soil water holding capacity over large areas to predict the potential production of forest stands. Geoderma 160:355-366

Piedallu C, Gégout J-C, Perez V, Lebourgeois F (2013) Soil water balance performs better than climatic water variables in tree species distribution modelling. Glob Ecol Biogeogr 22:470-482

Piotto D (2008) A meta-analysis comparing tree growth in monocultures and mixed plantations. For Ecol Manag 255:781-786

Plummer M (2003) JAGS: a program for analysis of Bayesian graphical models using Gibbs sampling. In Proceedings of the 3rd International Workshop on Distributed Statistical Computing (DSC 2003). March pp. 20-22

Pretzsch H (2003) The elasticity of growth in pure and mixed stands of Norway spruce (Picea abies [ L .] Karst .) and common beech ( Fagus sylvatica L.). J For Sci 49:491-501

Pretzsch H (2005) Diversity and productivity in forests: evidence from long-term experimental plots. In: Scherer-Lorenzen M, Körner C, Schulze E-D (eds) Forest Diversity and Function, Ecological Studies Vol. 176

Pretzsch H, Schütze G (2016) Effect of tree species mixing on the size structure, density, and yield of forest stands. Eur J For Res 135:1-22

Roscher C, Schumacher J, Gubsch M, Lipowsky A, Weigelt A, Buchmann N, Schmid B, Schulze E-D (2012) Using plant functional traits to explain diversity-productivity relationships. PLoS One 7: e36760

Ryan MG, Stape JL, Binkley D, Fonseca S, Loos RA, Takahashi EN, Silva CR, Silva SR, Hakamada RE, Ferreira JM, Lima AMN, Gava JL, Leite FP, Andrade HB, Alves JM, Silva GGC (2010) Factors controlling Eucalyptus productivity: how water availability and stand structure alter production and carbon allocation. For Ecol Manag 259:1695-1703

Scherer-Lorenzen M, Körner C, Schulze E-DD, Korner C, Schulze EDD, Körner C (2005) Forest diversity and function. Ecological Studies Vol. 176, p. 399, Springer

Silva Pedro M, Rammer W, Seidl R (2017) Disentangling the effects of compositional and structural diversity on forest productivity. J Veg Sci 28:649-658

Soares AAV, Leite HG, Souza AL, Silva SR, Lourenço HM, Forrester DI (2016) Increasing stand structural heterogeneity reduces productivity in Brazilian Eucalyptus monoclonal stands. For Ecol Manag 373: 26-32

Tilman D, Reich PB, Isbell F (2012) Biodiversity impacts ecosystem productivity as much as resources, disturbance, or herbivory. Proc Natl Acad Sci 109:10394-10397

Turc L (1961) Estimation of irrigation water requirements, potential evapotranspiration: a simple climatic formula evolved up to date. $\mathrm{J}$ Annu Agron 12:13-14

Valbuena R, Packalén P, Martin-Fernández S, Maltamo M (2012) Diversity and equitability ordering profiles applied to study forest structure. For Ecol Manag 276:185-195

Vallet P, Pérot T (2011) Silver fir stand productivity is enhanced when mixed with Norway spruce: evidence based on large-scale inventory data and a generic modelling approach. J Veg Sci 22:932-942

Vilà M, Vayreda J, Comas L, Ibáñez JJ, Mata T, Obón B (2007) Species richness and wood production: a positive association in Mediterranean forests. Ecol Lett 10:241-250

Vilà M, Carrillo-Gavilán A, Vayreda J, Bugmann H, Fridman J, Grodzki W, Haase J, Kunstler G, Schelhaas MJ, Trasobares A (2013) Disentangling biodiversity and climatic determinants of wood production. PLoS One 8:e53530

Wernsdörfer H, Colin A, Bontemps JD, Chevalier H, Pignard G, Caurla S, Leban JM, Hervé JC, Fournier M (2012) Large-scale dynamics of a heterogeneous forest resource are driven jointly by geographically varying growth conditions, tree species composition and stand structure. Ann For Sci 69:829-844

Whittaker RJ (2010) Meta-analyses and mega-mistakes: calling time on meta-analysis of the species richness-productivity relationship. Ecology 91:2522-2533

Zeller L, Liang J, Pretzsch H (2018) Tree species richness enhances stand productivity while stand structure can have opposite effects, based on forest inventory data from Germany and the United States of America. Forest Ecosystems 5:4

Zhang Y, Chen HYH (2015) Individual size inequality links forest diversity and above-ground biomass. J Ecol 103:1245-1252

Zhang Y, Chen HYH, Reich PB (2012) Forest productivity increases with evenness, species richness and trait variation: a global meta-analysis. J Ecol 100:742-749 